\title{
China's Central-Local Government Relationship from the Fiscal System Perspective
}

\author{
Xiaochun Ren, Lingguang Meng* \\ School of Political Science and Public Management, Shanxi University, Taiyuan, P. R. China \\ Email address: \\ xiaochunr@163.com (Xiaochun Ren),18730262115@163.com (Lingguang Meng) \\ ${ }^{*}$ Corresponding author \\ To cite this article: \\ Xiaochun Ren, Lingguang Meng. China's Central-Local Government Relationship from the Fiscal System Perspective. Journal of Public \\ Policy and Administration. Vol. 4, No. 4, 2020, pp. 78-84. doi: 10.11648/j.jppa.20200404.13
}

Received: November 13, 2020; Accepted: December 2, 2020; Published: December 8, 2020

\begin{abstract}
Different fiscal systems may shape different relationships of the central-local government. The transition of the fiscal system is an important perspective to interpret the changes of the relationship between the central and local governments. From the perspective of historical institutionalism, this paper analyzes the changes of China's fiscal system and the corresponding central-local relationship since the founding of the People's Republic of China. Since 1949, China's fiscal administration system has undergone a continuous change process: the fiscal system characterized by "unified revenue and unified expenditure" in the prime of the founding of China, the fiscal system characterized by "fiscal responsibility" in 1980s (the reform and opening-up) and the fiscal system characterized by the tax-sharing system gradually improved. Accordingly, with the evolution of the fiscal system, the central-local relationship characterized by "centralization of authority", "decentralization and profit sharing" and "grant decision in economy" have been formed respectively. In view of the above, the conclusion is drawn: with the constant reform of the fiscal system, the relationship between the central and local governments is gradually moving from "control' and 'being controlled" towards "synergy and cooperation" in China. Finally, they will achieve a benign development.
\end{abstract}

Keywords: Fiscal System, Central-Local Government Relationship, Changes

\section{Introduction}

"The fiscal system not only affects the economy and development, but it is the key to effective governance. Its reform and remolding will become an unavoidable proposition on the way to explore the great country governance in the new era." [1] The reform of different fiscal systems inevitably results in different central-local government relationships. In 2013, China took "establishing a modern financial system" as the goal and positioned finance at a special height of "the foundation and important pillar of the national governance", which had an important effect on the central-local relationship. The research perspective viewing the change of the central-local government relationship by studying fiscal system changes has long existed in the academic circle, such as the finance has influence on the behavior of central and local social governance (Feizhou Zhou, \& Mingzhi Tan; 2014) [2]; the choice of the central government's fiscal strategy and the behavior logic of local governments (Chao Yuan, 2018)[3]; China's central-local government relationship excessively emphasized "political centralization" (Xiangdong Zhang, 2020) [4]. However, from cybernetics' perspective, these research results believed that the reform of the fiscal system is a political control means adjusting the central-local government relationship, and its purpose is to realize the effective control over local governments through adjusting the fiscal system. With the gradual change of the system and the development of the modernization of the national governance system, the central-local relationship change will have a new definition. The purpose of this paper is to find a new perspective researching the fiscal system changes and the central-local government relationship. 


\section{The "Unified Revenue and Unified Expenditure" with the "Centralization of Authority" (1949-1979)}

\subsection{The Fiscal System Characterized by "Unified Revenue and Unified Expenditure"}

Since the founding of the People's Republic of China (PRC), it had practiced the fiscal system characterized by "unified revenue and unified expenditure, unified management" in order to integrate the country's limited resources. This fiscal system regulated centralized authority that the central government controlled fiscal revenue from the local, and cured the insufficiency of local finance through appropriation. Under the background of the fiscal system characterized by "unified revenue and unified expenditure, unified management", financial power and financial resources were administrated by the central government. In 1953, the central government divided financial revenues and expenditures, implemented management level by level. The central government controlled financial power, which meant that local governments were not a financial subject. In 1958, the central government delegated decision-making power of arranging the expenditure in five years to local governments. But As the economy was in a downturn, this measure ended a year later. In 1959, the central government implemented "sharing in the total revenue, having a change every year" instead of executing above-mentioned measures. The central government gave main financial revenue to local government, and budgeted the financial expenditure according to the administrative relation. In 1961, the central government centralized financial management power and enterprise financial power. In 1968, the fiscal system characterized by "two roads" was carried. In 1971, "fixed and covered expenditure with revenue" was put into practice. In 1974, adjusting above-mentioned system, China stipulated that local governments obtain government revenue in a fixed proportion; if exceeding this proportion, it required the central government to set up an additional reserve proportion, named "offer higher" system. In 1976, the fiscal system named "integrating expenditure with revenue, sharing in the total revenue, having a change every year" was implemented. In 1978, there was a new fiscal system that some local governments implemented "integrating expenditure with revenue, sharing proportion of the increased revenue". In 1979, with the adjustment of economy policies, the factors of increasing expenditure and decreasing income increase, which made it difficult to carry out the fiscal system.

\subsection{The Central-local Government Relationship Characterized by "Centralization of Authority"}

The fiscal system characterized by "centralization of authority" integrated financial power, and promoted the economy of China. Under this fiscal system, all the financial work including the revenue and expenditure from local governments were controlled by the central government, and local governments were powerless.

The fiscal system characterized by "unified revenue and unified expenditure" played a positive role in developing the economy in the planned economy period. This fiscal system helped China economy to recover from that undone period since China was founded. However, there were some obvious drawbacks. When the central government centralized financial work, its power was expanding so quick that produce a structure that all the financial power was controlled by the central oneself, which suppressed the initiative of local governments and led to plodding economic development. While local governments long to motivate themselves positivity in developing economy, they are bound to use their financial decision-making power and pursue economic benefit, which will result in economic dislocation. This fiscal system hardly achieved a balance between the central finance and the local finance.

In that period, the fiscal system had an effect on the central-local government relationship and led to the state of "centralization of authority". Meanwhile, the central government always mastered the financial power. Even if giving some power on finance to the local, it depended on the central government's will. Shangli Lin considered that all fields have demonstrated centralization of authority in the 30 years since China was founded. Although, the central-local government power fluctuated between the two poles of centralization and decentralization in this period, this phenomenon existed only on the premise guaranteeing the absolute authority of the central government, and it was just a division of administrative power without political and legal significance. [5] Therefore, the central-local government relationship integrated economic and financial power in this period, and was named the central-local government relationship characterized by "centralization of authority".

\section{The "Fiscal Responsibility" with the "Decentralization and Profit Sharing" (1980-1993)}

\subsection{The Fiscal System Characterized by the "Fiscal Responsibility System"}

In 1980, there was the "dividing revenues and expenditures, implementing the fiscal responsibility system according to administrative rank". The basic principle of this system was to clarify the powers and responsibilities of local governments, exercise their respective rights and responsibilities, and give free rein to the initiative and creativity of central government and local governments. [6] In 1985, the fiscal system characterized by "dividing taxes, ascertaining revenues and expenditures, implementing the fiscal responsibility system according to administrative rank" made a certain adjustment that tax category became the standard of income and expenditure. In 1988, the trial of the local fiscal responsibility system was implemented. It was tried in all provinces, autonomous regions and municipalities directly under the 
Central Government except Guangzhou and Xi'an autonomous regions. This policy had six forms: increasing revenue, sharing in the total revenue, sharing in the total and growth revenue, responsibility of increased paid in, fixed paid in, fixed subsidies, which aimed to encourage local governments to actively levy tax and make retention increases with the rise of taxation.

\subsection{The Central-local Government Relationship Characterized by "Decentralization and Profit Sharing"}

\subsubsection{The Effect of the "Fiscal Responsibility System"}

Overall, becoming different from the past, the fiscal system characterized by "fiscal responsibility system" gave local governments more autonomy, which motivated local governments to take the initiative to create economic value in order to bring development opportunities to local governments. Though there were many positive effects, this system led to the narrow of the central financial power and the severe contraction in the central financial revenue. If things had gone on like this, the central government would have failed to function which could cause serious problems.

\subsubsection{The Central Government and Local Governments Under "the Fiscal Responsibility System"}

The fiscal administrative system characterized by "fiscal responsibility system" was designed to break the "centralization of authority" system of the central government since 1949 (the founding of China). In this context, the central government committed itself to local governments to achieve economic growth.

In 1985, a serious of new issues emerged. Areas with a large proportion of capital paid faced economic decline while the economy rapidly grew. These local governments believed that fiscal equalization pattern depending on "sharing in the total revenue" system seriously affected the reasonable growth of local revenue, producing a phenomenon that high financial revenue areas had a small proportion of financial revenue retained by local governments and a large proportion in capital paid. Meanwhile areas with low financial revenue had a large proportion of financial revenue retained by local governments and a large proportion in capital paid, which was named "those oxen which run faster get more whips". Based on this context, local governments commenced from the angle of extra-budgetary revenue and non-budget revenue, and replaced the budgetary revenue with it, so as to reduce the proportion of capital paid and obtain more benefits. As the enterprise income tax and turnover tax were divided on their ownership, and the enterprise income accounted for the majority of the local financial revenue, local governments "enriched the people", "enriched the enterprises". This measure implemented by local governments resulted in decline of the central financial revenue and economic downturn. "The fiscal responsibility system" was born at the right moment for resolving the issue of the central finance difficulty.

Responsibility-system broke "big rice pot" pattern, and achieved the change from centralized management by the central government to autonomous management by local governments, from departments to regions and from "sharing in the total revenue" to "sharing in revenue by category", which gave local governments more financial management power. Therefore, local governments had sufficient power to develop the regional economy independently. Finally, all regional economy bloomed together, which formed "the Guangdong model", "the Wenzhou model" and "the Southern Jiangsu model".

However, as many scholars believed, the "decentralization and profit sharing" by the central government to local governments will inevitably affect the overall regulatory and management capacity of the central government, making it difficult for the governmental functions to function normally and finally weaken the "state ability". Everything has the nature of profit-driven. Under the system of "the fiscal responsibility system", local governments inevitably committed to obtaining their own fiscal revenue and reduced the capital paid. Instead, the purpose that the central government carried out the fiscal responsibility system was to establish a principal-agent relationship between the central and the local and require local governments respond to collection on the central financial revenue. In this case, the central fiscal revenue was limited by the allocation proportion of central-local and the initiative of local governments. If local governments hadn't taken the initiative collecting taxation or the central share is few, it would have brought a shrinkage in the central financial revenue. The local economic strength increasingly grew and the central government's financial difficulties, which were directly reflected as the "two proportions" (the proportion of government revenue in the GDP and the proportion central revenue in government revenue). Finally, it seriously affected the legitimacy of the central authority.

This policy meant that when local governments got more financial power and resources, they were responsible for collecting revenue from the central financial. Local governments imposed downward taxes, in order to protect their own interests. Finally, it resulted in financial difficulties of grassroots government. For avoiding the "those oxen which run faster get more whips" phenomenon, the central government implemented six forms of "the fiscal responsibility system" in local governments, which broke "the sharing in the total revenue" pattern, caused the imbalance in local financial and made the gap in wealth became highlight.

From the above we mentioned, the central government tried to find a balance of distribution of financial power and resource between the central government and local governments. But as a result of local governments' profit-driven, the balance was not stable. On the contrary, the government's ability and efficiency in absorbing fiscal resource were declining rapidly, and the central fiscal capacity was seriously insufficient, which threatened the central government's authority. Decentralization goes beyond the bottom line [7]. So, the fiscal system needed a new round of reform. Under the fiscal responsibility system, there were many measures that the power from the central government 
devolved power to local governments. Therefore, the central-local government relationship was summarized as "decentralization and profit sharing" in this period.

\section{The "Tax-Sharing" with the "Grant Decision in Economy" (1994-)}

\subsection{The Tax-sharing System}

\subsubsection{The Basic Content of the Tax-sharing System}

With the change of the economic system, the financial management system should be adjusted accordingly. The financial management system of every economic stage has obvious economic system imprint.[8] Firstly, the problems caused by the reform of the fiscal system in the 1980s emerged gradually and became increasingly serious in the 1990s. When the central financial revenue got a reduction, local governments became relatively rich, and the central financial balance relied on the capital paid of local governments, and set up a "fund" whose revenue came from local governments in the 1980s. At the same time, the fiscal system named the tax-sharing system which was generally accepted by many states was fashionable in the international community, and the reform and opening-up process accelerated, the market economy gradually launched. Thus, the Chinese government actively introduced and adjusted it to fit China's reality. In the preliminary stage, the tax-sharing system meant implementing two sets of tax laws between the central and local governments so as to divide the fiscal revenue between the central and local governments. Later, it became a financial management system, and the tax division was only a part of the tax-sharing system. [9] Finally, the tax-sharing system was implemented in 1994.

Just as its name implies, the tax-sharing system is a classification of categories and rights about tax. There are many measures: taxes are divided into central tax, local tax and shared tax; establishing two major tax agencies, and the power to collect taxes is controlled by the central and local governments; the financial power is divided on the basis of rationally dividing the administrative powers of governments at all levels; setting up the system of tax return and transfer payment system from the central government to local governments. There are a chart concerning the main source of revenue of the central tax system, the local tax system and shared tax under the tax-sharing system.

Table 1. Tax Category in the Tax-Sharing System.

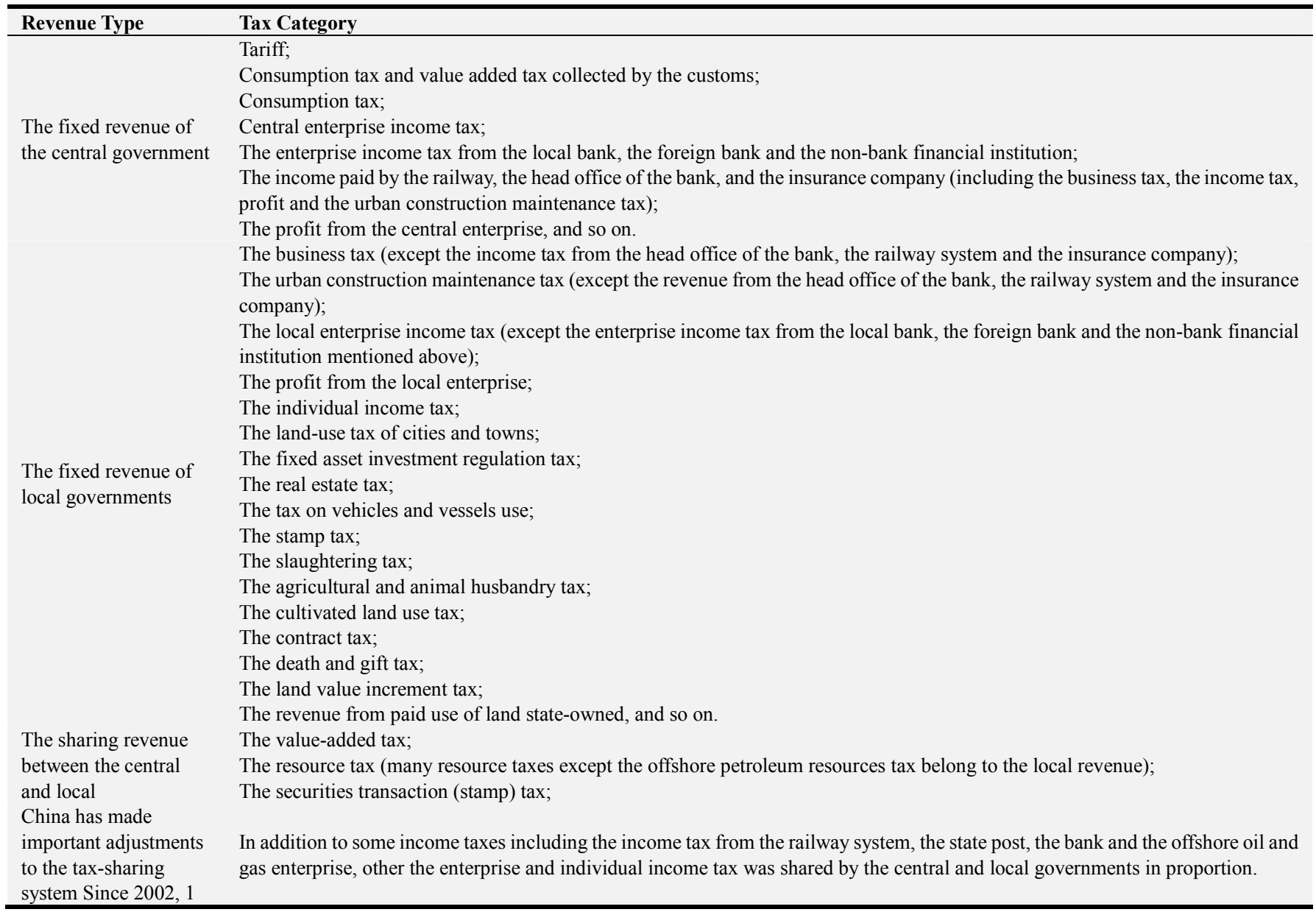

\subsubsection{The Adjustment Concerning the Tax-sharing System}

Since the tax-sharing system was carried out, the central government has made some adjustments about its basic principles and content in order to adapt to volatile situation. In 
spite of this, its spirit is constant. In 2002, there were some adjustments about the income tax made by the central government which regulated that the individual income tax and the enterprise income tax was shared by the central and the local in the same proportion (except a few special industries and enterprises). In 2003, China set the ratio to $6: 4$ between the central and the local, and required the central government to use its revenue for transfer payment. In 2004, the export rebates reform was put forward and it regulated the part being ahead of last year's share was undertaken by the central and local governments at 75:25. In 2015, the proportion undertaken by local governments decreased. Besides, the central government also made other adjustments such as increasing the share of the stamp tax on securities trading undertaken by it and added the items and amounts of tax rebates to local governments.

\subsection{The Central-local Government Relationship Characterized by "Grant Decision in Economy"}

\subsubsection{The Overall Impact of the Tax-sharing System}

The advantages of the tax-sharing system began to shine after it replaced the "fiscal responsibility" system. The development from the local fiscal responsibility system to the tax-sharing system meant that China's fiscal system was gradually institutionalized and standardized, and it replaced the previous uncertain policies with a new system, which was a great progress.

The fiscal administration system named by the tax-sharing system is an institution that is widely accepted by the international community. It was designed to increase the revenue of the central government. Hence there is the regulation of the tax-sharing system: the central tax mainly includes the state-level tax; the local tax mainly includes those taxes which are suitable to be levied by local governments according to administrative subordination; the shared tax mainly includes taxes that are not suitable to collect and manage by the central or local governments alone. Among the three categories above mentioned, the central government obviously accounts for the vast majority of fiscal revenue. The revenue of the central government has a huge increase, and the "two proportions" and "the state-ability" get an obvious promotion, which puts the central government in a stronger position than local governments.

As far as the tax-sharing system itself is concerned, as the most advanced fiscal system universally recognized by every state all over the world, its scientific nature is self-evident. But in the practice of states, there are a variety of issues. In the implementation of tax distribution system in China, there are several serious institutional problems: the first, local governments' power is indefinite; the second, the enterprise income tax is levied by local governments; the third, the shared tax accounts for quite high proportion in all the revenue; in the these troubles, the most serious problem is the definition of the administrative power. [10] The basic principle of the tax-sharing reform is to divide the financial power according to the administrative power, but the division of the financial power is universal instead of the division of administrative power ignored in reality. In 1994, the demarcation of the tax-sharing reform was an introduction about the context in that period, and it didn't make further progress. One salient feature of the sharing mode is the imbalance of the power and responsibility (the administrative power) of central and local. Although local governments may gain half of all the revenues, they bear more than $80 \%$ of the expenditure responsibility. [11] In terms of the division of administrative power and expenditure responsibility, local governments have less right of speech, and the central government has the decision-making power, which may lead to unreasonable division. [12] The administrative power is what the government should do, and its division means defining the government's functions: what the government should do and should not do, and finally reasonably divide the financial power on this basis, which needs to take a long time to figure this out. It is extremely difficult to make the administrative power clear, but it is an essential link for implementing the tax-sharing system.

\subsubsection{The Central Government and Local Governments Under the Tax-sharing System}

The central government under the tax-sharing system is a principal beneficiary. After collecting most the state's revenue through dividing tax, the central authority has been significantly enhanced. By setting up tax authorities and levying taxes separately, it avoids local governments to retain for itself; implements the transfer payment system to ensure the normal operation of local governments. The central government basically achieves the purpose of the tax-sharing reform, and financial resources focus on the central government. The central government takes the dominant position, and local governments have to rely on it. The central government implements fiscal constraints on local governments through the tax-sharing system. As the central government's fiscal revenue increasing, it strengthens the central government's economic control over local governments and incentive to local governments in finance and tax. [13]

Under this system, local governments dominated by the policy respond appropriately and seeks actively the development path suitable for the government at the corresponding level since the tax-sharing reform. When the central government accounts for the vast majority of fiscal revenue, local governments begin to explore a new revenue-resource, purse non-budget revenue and try to bargain with the central government to protect their interests.

Since the tax-sharing was applied, local governments in a passive position have begun to adjust their ways of the revenue growth. In the prime of the tax-sharing, the enterprise income tax was still collected by the administrative unit owning enterprises. For this reason, local governments concentrated on enterprises in their administrative division. In 2002, the central government made an adjustment about the income tax which setting the ratio on allocation of income 
taxes to $6: 4$ between the central and the local. As a result, the revenue of local governments has to rely on the business tax instead of enterprise. Since then, the tertiary industry and the construction industry have become the main income sources for local governments.

At the same time, local governments pay attention to the extra-budgetary revenue and the non-budget revenue. The tax-sharing system actually confines the scope of local governments' financial power. Although local governments' financial power is rising, the scope of local financial power is not expanded in the same proportion. Therefore, local governments are bearing the expenditure responsibility that is not commensurate with their financial power, which deviates from the goal of "consistent power and responsibility. [14] Finally local governments have to focus on non-budgetary funds in increasing revenue. Due to the government performance evaluation and the current system (local governments had relatively independent the financial, approval, legislative and economic power), local governments take promoting economic growth and expanding fiscal revenue as the goal. Under the condition of strict control over the budget revenue including the tax, increasing government's expenditure has to rely on a large number of extra-budgetary revenue. [15] The non-budgetary funds are not subject supervised and approved by the People's Congress, and local governments may extract and retain by themselves. The non-budget funds obtained by local governments are not limited in quantity and use, and can be fully utilized as free funds, and thus local governments take non-budget funds as their main revenue-source. At this time, the main sources of non-budget funds for local governments are the land transfer revenue and the agricultural reserve. However, due to the huge differences in the eastern and western China, the sources of non-budget funds for local governments are different. Because there are many acreages agricultural land in the middle and western China, the agriculture is the most important income-source for people in the middle and western regions, which leads to the phenomenon that local governments gain revenues through the reserve of the agricultural tax and the agriculture. Unlike the middle and the western regions, local governments obtain revenues mainly come from the development and transfer of the land in the eastern where the number of people is greater than the number of the land, and it is high cost of land. Some local governments are difficult to maintain the balance of financial revenue and expenditures and need to rely on the transfer payment of the central government to fill the financial gap, which leads to they begin to rely on the central government. Therefore, there is a scene of local governments asking the central government for projects in the spring every year, which has become an important the local financial revenue-resource. The goal of the tax-sharing system in enhancing the "two proportions" and "state-capacity" has been basically achieved, but the problems in weakening the disparity of financial resources and the public services level caused by the development-speed between different regions have not been solved. On the contrary, they have become more serious partly than before.
This means that the middle region lags far behind the eastern and western regions [16].

Different from the fiscal responsibility system, local governments under the tax-sharing system are free and fixable in collecting taxes. Because of the central government relatively-centralized, instead of being "managed dead", local governments under the tax-sharing system are constantly exploring new revenue-sources to maintain themselves functioning.

The central-local government relationship is characterized by "grant decision in economy" from the central to the local. On one hand, it grants the autonomy of local budgets. On the other hand, it emphasizes the unified leadership of the central government. This is the inevitable requirement of fiscal decentralization and the embodiment of the principle of democratic centralism system under the unitary system in China. [17] The tax-sharing reform in 1994 reconstructed the interest relationship between the central government and local governments and made the central government occupy the majority of the state fiscal revenue. We can see decentralization-power from the central government to local governments: the central government decentralizes parts of fiscal administrative power to local governments; reasonably dividing tax; setting up the tax shared by the central and the local, and so on. Meanwhile, when the central government collected the vast majority of state financial resources, a series of game behaviors made by local governments indicated that the central-local government relationship has become gradually negotiable and cooperative rather than lean to one side. Hence, the central-local government relationship under the tax-sharing system is named by "grant decision in economy".

\section{Conclusion}

Based on the fiscal system reform and the central-local relationship analysis above three stages, there is a conclusion: as the financial management system characterized by the tax-sharing is implemented, the central-local government relationship is no longer dominated by the central government unified centralization and decentralization, but under the premise of "political centralization". As a new fiscal system reform deepening and deeply adjust the tax-sharing system, it becoming more collaborative; with the constant interaction of the central and local government, it will move from absolute control to consultation and cooperation. Thus, a more benign central-local relationship will be formed, and it get rid of phenomenon that "if decentralizing power, it will mess up; if centralizing power, it will die". Therefore, it is necessary to understand the development of the relationship between fiscal system reform and the central-local government relationship from the perspective of synergies different from traditional studies, so as to carry out a new round of fiscal system reform, form a more reasonable central-local government relationship, and promote the modernization of national governance in the new era. 


\section{References}

[1] Wu Yuanlin (2018), Fiscal Reform and the "Double Movement" in China. Beijing Cultural Review, 2018 (05): 86-93.

[2] Zhou Feizhou, Tan Mingzhi (2014), The Central-Local Government Relations in Contemporary China. China Social Sciences Press.

[3] Yuan Chao (2018), The Fiscal Logic of the Changing Behavior of Government: Comments on Interest's Sake: Fiscal Relations and Local Government Behavior and Central-Local Government Relations in Contemporary China. China Public Administration Review, 2018, (03): 134-151.

[4] Zhang Xiangdong (2020), The Logic of the Change of the Relationship between the Central and Local Governments and Micro Mechanism of Policy Practice-On the Position of "Project System". Journal of Sichuan University (Philosophy and Social Science Edition), 2020 (05): 185-192.

[5] Lin Shangli (1998). Intergovernmental relations in China. Zhejiang People's Publishing House, 1998.

[6] Yang Shuming (2005). Financial relationship between governments. Wuhan University, 2005: 100.

[7] Wang Shaoguang (1997). The bottom of the decentralization. China Planning Press, 1997.

[8] Zhang Qiang, Zhan Zhiwei (2019). A Comparative Study on Historical Evolution of China's Fiscal System. Journal of Dongbei, University of Finance and Economics, 2019 (03): $18-27$.

[9] Wang Yuling (2016). From "the tax-sharing system" to "the hierarchical system": The optimization of financial administrative system. Sub National Fiscal Research, 2016 (02): 16-22.

[10] Jia Kang (2003). China's financial policy-brief review and analysis of effect. Collected Essays on Finance and Economics, 2003 (01): 26-36.

[11] Fu Minjie (2016). Twenty Years after the Tax-Sharing Reform: History of its development and the way forward. Sociological Studies, 2016, 31 (05): 215-240+245-246.

[12] Wen Lizhou, Zhu Quanrui, Zhou Yanpin, (2020). A Study of Changes in Intergovernmental Fiscal Relations in China. Economy and Management, 2020 (05): 36-42.

[13] Ren Xiaochun, Yan Feifei (2018). The Rules and Introspection of The Cooperative governance between central and local governments in China. Jiangxi Social Sciences, 2018, 38 (06): 195-201.

[14] Luo Weidong, Zhu Xiangyu (2018). The Symmetry of Local Fiscal Power and Expenditure Responsibility and Fiscal System Reforms in China since Tax Sharing Reform. Social Sciences in Nanjing, 2018 (04): 30-38.

[15] Xu Jingyong (2016). The Tax-sharing system, the land-capitalization, the Land-finance and urbanization-transformation. Fujian Tribune (The Humanities \& Social Sciences Monthly), 2016 (11): 5-9.

[16] Zhou Feizhou (2006). A Decade of Tax-Sharing: The System and its Evolution. Social Sciences in China, 2006 (06): $100-115+205$

[17] Xiong Wei (2019). The Local Fiscal Autonomy Along with the Tax Sharing System in China. Journal of Political Science and Law, 2019 (01): 64-77. 